\title{
SOCIAL INTERACTION RELIGIOUS COMMUNITIES IN ISLAMIC HIGHER EDUCATION
}

\author{
Barsihanor1; Zakiyah ${ }^{2}$; Galuh Nashrulah KMR ${ }^{3}$, Abdul Hafiz ${ }^{4}$ Siti Liani $^{5}$ \\ ${ }^{1}$ Islamic University of Kalimantan, Indonesia \\ ${ }^{1}$ Faculty of Islamic Studies \\ ${ }^{1}$ Contributor Email: barsihanor@uniska-bjm.ac.id \\ 2Islamic University of Kalimantan, Indonesia \\ ${ }^{2}$ Faculty of Islamic Studies \\ ${ }^{2}$ Contributor Email: Kikiayoenani@yahoo.com \\ ${ }^{3}$ Islamic University of Kalimantan, Indonesia \\ ${ }^{3}$ Faculty of Islamic Studies \\ ${ }^{3}$ Contributor Email: galuh.nashrulloh@uniska-bjm.ac.id \\ 4Islamic University of Kalimantan, Indonesia \\ ${ }^{4}$ Faculty of Islamic Studies \\ ${ }^{4}$ Contributor Email: abdulhafiz@uniska-bjm.ac.id \\ ${ }^{4}$ Faculty of Islamic Studies \\ ${ }^{5}$ Contributor Email: sitiliani16@gmail.com \\ ${ }^{5}$ Faculty of Islamic Studies
}

\begin{abstract}
The purpose of this study was to determine and analyze the forms and factors that influence social interaction between students of different religions at the Islamic University of Kalimantan Muhammad Arsyad Al-Banjari Banjarmasin. This research uses a qualitative approach, with the type of case study research. The data in this study were extracted through in-depth interview techniques. observation, and documentation. Then the data analysis was performed using the Miles and Huberman model. The results showed that social interaction between Muslim and non-Muslim students was well adapted, their adaptive attitude would result in a desire to cooperate and help each other for the same goal, which is a cooperative associative social process, and this cooperative associative social process shapes their attitude to mutual respect for differences in beliefs which is an accommodative associative social process. Social interaction between students of different religions at UNISKA is influenced by religious learning and Islamic campus culture.
\end{abstract}

Keywords; : Social Interaction, Religious Peopl 


\section{A. Introduction}

Humans are known as social beings, where humans cannot live without the help of others and always depend on others. That is, in social life, every human being will always have social interactions with one another. Social interaction is a dynamic social relationship concerning the relationship between individuals, between groups of people, and between individuals and groups of humans. Social interaction is also referred to as a relationship between individuals and other individuals, one individual can influence another individual or vice versa, so there is a reciprocal relationship. This relationship can be between individuals, individuals with groups and groups with groups. Through social interaction, each individual can create a very solid relationship, because harmony has been created in terms of understanding with one another. According to Soekanto in Sujarwanto (2012), a social interaction will occur if it meets 2 conditions, namely social contact and communication. This also has an impact on relations between religious communities. Interaction has brought about a reciprocal change in attitude, where the interaction between religious communities becomes more orderly so as to minimize conflict.

Indonesia is a pluralistic country, one form of pluralism in Indonesian society is that of religion. Religious plurality is a reality that cannot be denied or even eliminated. The social harmony created in the community becomes a very important social fact for different groups of people in the midst of progress. In facing such plurality, of course we cannot take an anti-pluralism stance. Harmonization will be created if every society realizes and respects diversity (Gina Libra \& Ikhwan Ikhwan, 2019). This fact leads to a logical consequence in religious life, namely to live side by side in different beliefs. The implementation of tolerance will only be realized if people behave well at every step, both to people who have the same or different religions as themselves. These attitudes will not emerge by themselves without being based on education, both formal and informal education as well as good morals by humans. 
Failure to create tolerance will result in conflicts such as the one in Tolikara Regency. The failure to tolerate this resulted in the burning of mosques by Christians before the implementation of the Eid prayer. A similar case also occurred in the land of Aceh, Singkel district on Tuesday, October 13 2015, where people who were dissatisfied with the agreement of the local government and community groups regarding 21 churches whose permits were deemed problematic, then hundreds of masses moved using motorbikes and pickup trucks to their homes. worship is at issue so that the burning of the Church takes place.

The events that occurred in Singkel were caused by the displeasure of Muslims with the ways Christians developed their teachings. In addition, the Christian attitude is considered by Muslims to lack respect for their existence, such as building churches without permission, releasing pigs and bringing their meat to the Muslim community. Some Muslims reacted strongly to these actions by Christians. The attitudes of Christians are considered by Muslims to lack respect for their existence, such as building churches without permission, releasing pigs and bringing their meat to the Muslim community. Some Muslims reacted strongly to these actions by Christians. In fact, religious conflicts can be caused by various things, it can be in the form of differences in doctrine and attitudes, differences in ethnicity and race, cultural differences, as well as problems of the majority and minority, therefore the role of religious leaders is very influential in maintaining inter-religious tolerance (Indah Permata Sari, 2020).

Places of worship that are most vulnerable to triggering religious conflict are as indicated by research conducted by Rina Hermawati et al. found the same possibility that conflicts are generally triggered by permits for construction of houses of worship that are within the domain of government authority, so this is important to be addressed in order to increase the achievement of the Tolerance Index (Hermawati, R., Paskarina, C., \& Runiawa, 2016) The same thing was also found in Aliffiati's research, the conflict that occurred was mostly experienced by Hindus and Muslims which was triggered by the case of permits to establish places of worship for Muslims (Aliffiati, 2014) 
The Islamic University of Kalimantan Muhammad Arsyad Al-Banjari Banjarmasin or better known as UNISKA is one of the Islamic universities in South Kalimantan. Uniska is the largest private campus in Kalimantan with various faculties and study programs, although as an Islamic university, UNISKA is open to non-Muslims to study and continue their education. Until now, UNISKA has 641 Non-Muslim students consisting of 428 Protestants, 111 Catholics, 85 Hindus and 12 Buddhists spread across various faculties. Although the various religions in UNISKA have never had conflicts between Muslim and non-Muslim students, the behavior of tolerance and not differentiating between religions has grown well.

The realization of tolerant behavior among students who have different religions will further support the realization of the university's vision as an Islamic educational institution. A quality Islamic education institution is characterized by the creation of good interactions at the institution. These various facts encourage research on social interaction between religious communities at the Islamic University of Kalimantan, Muhammad Arsyad Al-B

\section{B. Method}

This research uses a qualitative approach with the type of case studies. The data in this study were extracted through in-depth interview techniques. In in-depth interviews, researchers conducted interviews with informants. Besides in-depth interviews, researchers also made observations, and extracted data through documents. Observation and document extracting. After all the data has been collected, the next step is to analyze the data. The data analysis model carried out in this study used Miles and Huberman. The first step in data analysis is to classify the collected data, then identify the data. data reduction and drawing conclusions.

\section{Finding and Discussion}

\section{Finding}

Islam Kalimantan MAB which is better known as UNISKA has heterogeneous students in terms of religion and ethnicity. There are at least five religions, namely Islam, Christianity, Catholicism, 
Buddhism and Hinduism that are practiced by students. Based on 2018 forlap data, UNISKA has a total of 18,637 students, with details of 17,000 being Muslim, 428 Protestant, 111 Catholic, $85 \mathrm{Hindu}$, and 12 Buddhist. Even though as a campus that has a variety of student religions, this does not cause social interaction between Muslim and non-Muslim students to cause problems, instead the interactions are built very well, without any discrimination against students with minority religions.

The interactions that are built are like interactions between human beings without seeing and considering the background of religious differences between students when interacting. Religious differences are not an obstacle for students to mingle in socializing. Students, both Muslim and non-Muslim, do not use religion as an excuse not to interact with each other. In fact, their different religions have made it an arena to exchange knowledge regarding their respective religions.

Social interactions that occur on campus are not only when meeting outside of class, but also when lessons are in progress. When the lesson is in progress, the interaction between Muslim students and non-Muslim students begins when the lecturer gives them the material. Muslim students and non-Muslim students do not only interact with fellow students but also with lecturers. The interaction between students and lecturers occurs during the lecture process. Lecturers provide the same treatment to all students.

Good interactions among students can also be seen during the learning process in class. The growth of tolerance in each student is shown to Muslim and non-Muslim students, when they are united into a group in assignments, it seems that there is no grouping according to religion or rejection of group members because of differences in beliefs, this certainly indicates harmonization in socializing in class. Furthermore, this harmonization is also manifested in the form of cooperation carried out by group members, it is created due to their own awareness. Collaboration in groups occurs in working on group assignments or papers, either in making 
or presenting. Factors that influence social interaction between religious communities at the Islamic University of Kalimantan Muhammad Arsyad Al-Banjari Banjarmasin.

\section{Discussion}

The findings from the results of data collection have led to forms of social interaction that occur between individuals, individuals or groups with groups, and within these individuals. Social interaction is the basis of social processes that refer to relationships (Khotimah, 2016). Ditha Prasanti also explained that interaction is a reciprocal relationship between two or more people, and each person involved in it plays an active role (Ditha Prasanti \& Sri Seti Indriani, 2017).

The form of social interaction between individuals is the acceptance of Muslim students against non-Muslim students, this acceptance is based on cultural similarities and similarities in norms in their respective religions. The form is in the form of non-Muslim students wearing neat and polite clothes even though they do not wear a headscarf, and Muslim students still accept it by not forcing to wear a veil. In general, campus life is dominated by Islamic culture such as Islamic dress, because the majority of students studying at UNISKA are Muslim. This is similar to what was expressed by Arifuddin (2009) if the majority group usually determines the collective identity of a society. However, if differences and diversity can be managed properly, it will become a new entity that can be used as a unifying tool for society (Umi Hanik \& Moh. Trumudi, 2020).

The form of individual social interaction with groups is the openness of Muslim students, the majority of which is towards each individual, from non-Muslim students. This is in line with what Muhammad Mushfi El Iq (2017) explains, indicators of the creation of social skills are marked by the ability to communicate, work together, participate in society, and social sensitivity. The attitude of cooperation to understand and help each other regardless of differences makes it more harmonious and easier to interact (Siska Saputri, Rosichin Mansur, 2019). 
The form of interaction between students of different religions is illustrated in learning activities together when doing class assignments. In this group, the tasks of each individual are not classified based on religion and culture, but each individual does what he can do, so that this form of interaction creates a cooperative associative social process. Priyo Dari Molyo \& Faizul Maulidah (2018) revealed that when someone in a community member often carries out activities together with one of the other members, personal closeness between the two will be built together. Interaction is well established between students and lecturers during the lecture process. Lecturers provide the same treatment to all students. This is in line with what Abudin Nata said in Harizal Anhar (2013) that educative interactions contain good values that are built up between educators and students, including mutual respect for each other. Imam alGhazali also revealed that a teacher's morals are more important than the knowledge they have (Anhar, 2013). Educators must be able to build good communication with their students. This is also an approach in order to make students comfortable and not feel strange with the presence of educators. This is also part of the message of Q.S an-Nahl verse 125 (Saifullah Idris \& Tabrani ZA, 2017)

In the concept of educational interaction, the perspective of the Qur'an states that educators are components in educational interactions and educators have a more role. Therefore, an educator must have competencies (the basic nature of educators), including wise, compassionate, democratic, know students and understand their psyche, are knowledgeable, understand the material, are patient and sincere (Mollah, 2015). In line with Imam Al Ghazali's opinion, which explains the ethics of teacher and student interaction, including, showing affection for students, prioritizing purity of soul from disgraceful morals, having teacher competence and achieving national education goals, as well as the goals of Islamic education (Indriyanti et al., 2017). 
The social interactions that occur within individuals of Muslim and non-Muslim students are based on cultural similarities and similarities in religious norms, such as non-Muslim students who do not wear a headscarf but still maintain modesty in dressing, because modesty in dressing is a culture in Indonesia. Meanwhile, Muslim students do not discriminate against non-Muslim students who do not wear the hijab. Two psychological activities of two individuals of different religions but of the same culture give rise to adaptive psychological attitudes and an accommodative associative social process appears. Islam places great emphasis on the importance of maintaining good relations between human beings. This is expected to construct a social system in society so that they can live in peace, harmony, not being divided, more tolerant, and loving each other (Arsyad \& Rama, 2019)

Referring to Rosenberg's identity theory, 1981; Stryker, 2008, which patterns the symbolic structure of interaction into reactions to form selfconception, self-conception produces interactions, interactions form human action. From these items, it can be symbolized by the forms of interaction that occur at the Uniska campus. The reaction items are in the form of individual acceptance, self-conception in the form of adaptive psychological attitudes, interactions in the form of accommodative associative social processes, and human action in the form of cooperative associative social processes. So that the applicative pattern can be formulated into the acceptance of Muslim students towards non-Muslims, it will shape their attitude to adapt to one another, and their adaptive attitude will result in a desire to work together and help each other for the same goal which is a cooperative associative social process, and the process This cooperative associative social forms their attitude to respect each other's differences which is an accommodative associative social process.

Fauzi Ismail revealed that the interaction takes place harmoniously if an agreement has been made to respect, respect and even consider each other as siblings and there is freedom for each citizen to carry out religious rituals according to their respective beliefs and not interfere with 
each other (Ismail, 2017). Suparman Jayadi, et al. (2017) Social interaction between Hindu and Muslim religious groups is based on awareness built from rational and irrational actions.

One of the factors that influence this social interaction is religious knowledge. Religious knowledge is contained in several religious subjects such as tawhid (in Islam). Besides, it is also necessary to have religious knowledge for other religions. This religious knowledge is needed to deepen the spirituality of individual religious followers. This religious knowledge will shape beliefs, and beliefs affect how people practice their religion, and also how they experience themselves and their world (Barsalou, L., Santos, A., Barbey, A., \& Simmons, 2005). This religious knowledge becomes the capital of individual religious followers to interact with social conditions that have religious diversity.

\section{Conclusion}

The acceptance of Muslim students towards non-Muslims will shape their attitudes to adapt to one another, and their adaptive attitude will result in a desire to work together and help each other for the same goal which is a cooperative associative social process, and this cooperative associative social process shapes their attitude. to respect each other's differences which is an accommodative associative social process.

\section{Acknowledgment}

The researcher would like to express his deep gratitude to the Directorate of Higher Education of Islamic Religion, Directorate General of Islamic Education, Ministry of Religion of the Republic of Indonesia for funding this research.

\section{Bibliography}

Aliffiati. (2014). Interaksi Sosial Antarumat Beragama di Perumahan Bumi Dalung Permai Desa Dalung, Kuta Utara, Badung. Kajian Bali, 4(1).

Anhar, H. (2013). Interaksi Edukatif Menurut Pemikiran Al-Ghazali. Jurnal Ilmiah Islam Futura, 13(1), 28. https://doi.org/10.22373/jiif.v13i1.570 
Arifuddin Ismail. (2009). Interaksi sosial antara kelompok masyarakat islam dan kristen di kota ternate. Al-Qalam, 15(24), 373-384.

Arsyad, M., \& Rama, B. (2019). Urgensi Pendidikan Islam dalam Interaksi Sosial Masyarakat Soppeng: Upaya Mewujudkan Masyarakat Madani. Al-Musannif: Journal of Islamic Education and Teacher Training, 1(1), $1-18$. https://jurnal.mtsddicilellang.sch.id/index.php/al-musannif

Barsalou, L., Santos, A., Barbey, A., \& Simmons, W. K. (2005). Embodiment in Religious Knowledge. Journal of Cognition and Culture, 5(1).

Ditha Prasanti \& Sri Seti Indriani. (2017). Interaksi Sosial Anggota Komunitas Let's Hijrah dalam Media Sosial Group Line. The Messenger, 9(2), 143-152.

Gina Libra \& Ikhwan Ikhwan. (2019). Pola Interaksi Sosial Masyarakat Muslim dengan Masyarakat Non Muslim di Jorong Sentosa Nagari Panti Kecamatan Panti Kabupaten Pasaman. Culture \& Society: Journal of Anthropological Research, 1(1), 77-83.

Hermawati, R., Paskarina, C., \& Runiawa, N. (2016). Toleransi Antar Umat Beragama di Kota Bandung. UMBARA: Indonesian Journal of Anthropology, 1(2).

Indah Permata Sari. (2020). Interaksi Sosial antar Umat Beragama di Kecamatan Lut Tawar Aceh Tengah. Sosiologi Agama Indonesia, 1(1), 96-106.

Indriyanti, T., Siregar, K. I., \& Lubis, Z. (2017). Etika Interaksi Guru dan Murid Menurut Perspektif Imam Al Ghazali. Studi Al-Qur'an, 11(2), 129-144. https:// doi.org/10.21009/jsq.011.2.03

Ismail, F. (2017). Interaksi Sosial Masyarakat Lawe Sigala-Gala Kabupaten Aceh Tenggara: Suatu Kajian Tentang Toleransi Antar Umat Beragama. Adabiya, 19(2), 81-100.

Khotimah. (2016). Interaksi Sosial Masyarakat Islam dan Kristen di Dusun IV Tarab Mulia Kecamatan Tambang Kabupaen Kampar. Penelitian Sosial Keagamaan, 19(2), 240-249.

Mollah, M. K. (2015). Konsep Interaksi Edukatif dalam Pendidikan Islam dalam Perspektif Al-Qur'an. Jurnal Pendidikan Islam, 3(2), 235-256.

Mushfi, M., \& El Iq. (2017). Model Interaksi Sosial Dalam Mengelaborasi 
Keterampilan Sosial. Pedagogik, 04(02), 211-227.

Priyo Dari Molyo \& Faizul Maulidah. (2018). Atraksi Interpersonal pada Komunitas Beda Agama. Nomosleca, 4(1), 703-713.

Saifullah Idris \& Tabrani ZA. (2017). Realitas Konsep Pendidikan Humanisme dalam Konteks Pendidikan Islam. Edukasi, 3(1), $96-$ 113. https://doi.org/10.1097/00001888-199901001-00046

Siska Saputri, Rosichin Mansur, dan I. J. (2019). Toleransi Beragama Siswa dalam Interaksi Sosial di Sekolah Menengah Kejuruan Negeri 2 Singosari Malang. Vicrantina, 4(6), 159-167.

Sujarwanto, I. (2012). Interaksi Sosial Antar Umat Beragama (Studi Kasus pada Masyarakat Karangmalang Kedungbanteng Kabupaten Tegal. Journal of Educational Social Studies, JESS, 1(2).

Suparman Jayadi, Argyo Demartoto, \& D. T. K. (2017). Interaksi Sosial Umat Hindu dan Muslim dalam Upacara Keagamaan dan Tradisi Perang Topat di Lombok. Analisa Sosiologi, 6(2), 54-63.

Umi Hanik \& Moh. Trumudi. (2020). Slametan sebagai Simbol Harmoni dalam Interaksi Sosial Agama dan Budaya Masyarakat Desa Tanon Kecamatan Papar Kabupaten Kediri. Tribakti: Jurnal Pemikiran Keislaman, 31(1), 135-152. 